\title{
THE USE OF PROCESS-PRODUCT HYBRID APPROACH TO IMPROVE STUDENTS' WRITING SKILLS
}

\author{
Yayan Suryana \\ Department of English Education, Faculty of Teachers Training and Education, \\ University of Kuningan, Indonesia \\ E-mail: ysuryana2008@gmail.com \\ Deden Iskandar \\ Department of English Education, Faculty of Teachers Training and Education, \\ University of Kuningan, Indonesia \\ E-mail: iskandardeden23@gmail.com
}

APA Citation: Suryana, Y. \& Iskandar, D. (2015). The use of process-product hybrid approach to improve students' writing skills. Indonesian EFL Journal, 1(2), 164-172

Received: 02-04-2015

Accepted: 06-05-2015

Published: 01-07-2015

Abstract: This paper comes out of concerns about teaching English writing to vocational high school students in EFL learners' context. This study points out how the process-product hybrid approach affects students' writing skills in solving some complex problems in order to generate deep comprehension of writing. In this study, quasi-experimental research was applied to measure the students' writing improvement by collecting the data from instruments which covered pre-test, posttest, and questionnaire. The findings showed that students' writing skill improved significantly. It also revealed that almost all of the students responded the statements positively and they believed that this approach can help them in improving their writing skill since it gives full comprehension of writing and serves more interesting teaching learning activities. Therefore, this integrated approach has become the most recommended approach for teachers to improve students' writing competences. Keywords: process-product hybrid approach, teaching English writing, students' writing skills.

\section{INTRODUCTION}

Over the years, it has seemed that writing has been seen as only a support system for learning grammar and vocabulary, rather than as a skill in its own right (Harmer, 2004) Moreover, in the EFL countries, this skill is very rarely practiced by students in the learning processes since it is thought as the most complex one. Because of its complexities, "it is harder to get such skill as the EFL learners only get some limited exposure of English, as most of them tend to use English in formal situation not in their daily communication, and the exposure of English is also limited to a few hours per week" (Kim \& Kim, 2005, p 2). Consequently, the EFL learners' ability to write in English is still low.

Writing is considered as an extremely complex cognitive activity, as the writer is required to demonstrate control of a number of variables simultaneously. At the sentence level, this skill includes control of content, format, sentence structure, vocabulary, punctuation, spelling and letter formation; and beyond the sentence, the writer must be able to structure and integrate information into cohesive and coherent paragraphs and texts (White 1981, as cited in Nunan, 1989 and Tribble, 2003).

In order to overcome such complexities of writing skill, this research was formulated to create students' balance competences by using an integrated approach called "processproduct hybrid" (Tangpermpoon, 2008, p. 7), as a result of the three combination of writing approaches proposed by Harmer (2001); the process-based approach, product-based approach, and genre-based approach. This integrated approach offers the EFL learners a model to generate deep comprehension of how to construct text grammatically in the product-based approach, know the linguistic skills on the steps of writing a text in the process-based approach, and understand the 
writing purpose of their texts in the genrebased approach.

By using the integrated approach, it is assumed that although the EFL learners only get very limited exposure of English, they can practice this skill within the very limited time with the full understanding they gain through the process of learning by using processproduct hybrid approach. In this case, before teaching writing by using this integrated approach, the EFL teachers should be aware that the three approaches included to this integrated approach have their own characteristics which cover their strengths and weaknesses (Tangpermpoon, 2008), and their characteristics are elaborated below:

\section{A product-based approach is "a}

traditional approach, in which students are encouraged to mimic a model text, usually is presented and analyzed at an early stage" (Hasan \& Akhand, 2010, p. 78). This traditional approach focused on the final written product (Mourssi, 2013), so it has been called by several names: the controlledto-free approach, the text-based approach, and the guided composition.

Basically, writing in product-based approach has served to reinforce EFL writing in terms of grammatical and syntactical forms. There are variety of activities in product-based writing which can raise students' awareness in EFL writing from the lower level of language proficiency to advance like English major students such as the use of model paragraphs, sentencecombining, and rhetorical pattern exercises. Those activities are viewed as "the simple linear model of the writing process which proceeds systematically from prewriting to composing and to correcting" (Tribble, 2003, p. 3). Besides, teachers and learners believe that planning stage of writing in text-based approach begins and finishes in the primary period of composition.

The pattern-product writing approach is widely accepted among teachers because they have found several advantages in it for the writing classroom, such as:

a. Learners learn how to write in English composition systematically from using the pattern-product techniques, namely the logic of English rhetorical patterns such as narration, description, and persuasion.

b. Learners also learn how to use vocabulary and sentence structures for each type of rhetorical pattern appropriately.

c. Product-based writing helps teachers to raise EFL learners' writing awareness, especially in grammatical structures. However, there are also disadvantages associated with the use of the product-based writing like what is stated below:

a. Writing with product-based approach gives little attention to audience and the writing purpose since learners and instructors tend to overemphasize on the importance of grammar, syntax, and mechanics.

b. Learners will have lack motivation in learning and high pressure in creating their writing tasks, as their instructors mostly focus on the accuracy of the language structures.

In order to teach writing for students, teachers should keep the strengths of the product-based writing approach to be used as a part of the integrated approach because the rhetorical patterns in this approach will help learners who have a certain amount of background knowledge in writing to write the organizational conventions appropriately. Besides, learning pattern-product will help to shape students' writing competence and allow them to create their written product in academic settings effectively in terms of language use.

Process-based writing is viewed as the way writers actually work on their writing tasks from the beginning stage to the end of the written product. It is defined as the concept of an activity in which teachers encourage learners to see writing not as grammar exercises, but as the discovery of meaning and ideas. Through the various stage of writing processes, "students are trained to construct process-oriented writing that will affect their performance directly since it is a kind of student-centered approach" (Miri, 2014, p. 164). To have an effective performance, teachers need to "systematically teach students problem- 
solving skills connected with the writing process that will enable them to realize specific goals at each stage of the composing process" (Richards \& Renandya, 2002, p. 316).

During the writing process, teachers can enable learners to explore their thoughts and develop their own writing by using the fivestep writing process:

a. Prewriting

Teachers will provide a writing task and help students to generate vocabulary and ideas by applying a number of strategies in class namely brainstorming, clustering, and discussion, without concern for correctness or appropriateness in the first stage of writing.

b. First draft composing Learners will use vocabulary and ideas which they have got from the previous stage to express what they want to convey in their writing.

c. Feedback

In this writing stage, learners will receive comments from real audiences which can be a writing teacher or their peers and move on to new ideas in another draft. This interaction in groups can be a productive strategy in writing (Mourssi, 2013: 739).

d. Second draft writing Based on the comment of teachers and peers, learners will modify their previous draft by revising, adding, and rearranging ideas.

e. Proofreading

In the final stage, students will not only discover new ideas and language forms to express their ideas in writing but also focus on the appropriate use of vocabulary, layout, grammar, and mechanics.

Writing in the process approach can thus be seen as a dynamic and unpredictable process (Tribble, 2003), while writers try to reformulate their ideas and approximate the meaning of what they want to express in their work. This approach is well-known tool for teachers to teach EFL writing since they have a number of benefits, for instance: a. Learners are able to learn how to compose writing in English with little or no when process-based writing is compared to other writing approaches.

b. Learners can improve their writing step by step since instructors will guide them through the whole process of their writing tasks by giving them feedback and enough time and opportunity through peer and teacher review to develop a sense of audience (Boughey, 1997, p. 131), which allows them not only to reflect upon their previous writing but also to consider the possible existence of other viewpoints. In spite of being widely used in EFL composition, process-based writing still has some limitations like what are stated below:

a. Learners have to spend quite a long time to complete one particular piece of writing in the classroom.

b. Badger and White (2000, p. 157) also point out that "learners have no clear understanding about the characteristics of writing and are provided insufficient linguistic input to write in L2 successfully in a certain text type".

In order to alleviate the weaknesses in the integrated approach, the typical process writing model should be modified in the following ways:

a. Teachers should provide learners with some examples of the text type that they have to write so as to allow them to have a clear understanding about the aim and the framework of a particular writing type (by involving productbased approach).

b. Teachers should not spend too much time on one piece of writing in the class because this may decrease students' learning motivation and impede them from learning other types of writing. They should train students to develop a concept of audience by taking turns giving comment on their classmates' writing.

Genre-based approach considers writing as a social and cultural practice. The purpose of this writing involves the context where the writing occurs, and the conventions of the 
target discourse community. In this sense, "relevant genre knowledge needs to be taught explicitly in the language classroom" (Hasan \& Akhand, 2010, p. 81).

The genre-based approach can be called differently such as the "English for Academic Purposes approach" or the "English for Specific Purposes approach", they stress the importance of various types of writing which are tied closely to social purposes (Kim \& Kim, 2005, p. 5). In accordance with Badger and White (2000, p 155), "writing in the genre-based approach is regarded as an extension of the product-oriented approach since learners have an opportunity to study a wide variety of writing patterns", for instance, the business letter, the academic report, and the research paper. This approach argues that "students can only produce a composition to be successfully accepted by a particular English-language discourse community once they take context of a text into account into their own writing papers" (Tuan, 2011, p. 1472).

Like other writing approaches, the genrebased approach is increasingly used in the EFL writing classroom due to having certain strengths, such as:

a. The focus of writing in this approach aims to integrate the knowledge of a particular genre and its communicative purpose, these help learners to produce their written products to communicate to others in the same discourse community successfully.

b. By learning specific genre construction, it can be considered as a way to help learners come up with appropriate actual writing in their real life outside the classroom.

c. Genre-based approach also increases learners' awareness of such writing conventions as organization, arrangement, form, and genre.

d. Through the composing process, genrebased writing reflects a particular purpose of a social situation and allows students to acquire writing skills consciously by imitation and analysis of each writing genre (Badger \& White, 2000, p. 156). In contrast with the advantages of using genre-based approach above, there are also some weaknesses of this approach such as follows:

a. Learners may not have enough knowledge of appropriate language or vocabulary to express what they intend to communicate to a specific audience.

b. As Badger and White (2000, p. 157) point out, is that "the genre-based approach undervalues the writing skills which learners need to produce a written product and ignores the writing abilities learners have in other areas".

The strengths and weaknesses of each writing approach described above show that the three approaches are complemented one another. Therefore, teachers should use the combination of strengths from genre, product, and process approaches as a model to teach and improve students' writing skills.

To integrate each approach in the writing class, Tangpermpoon (2008, p. 7) points out that teacher may follow the following steps, (1) Teachers need to provide a clear model of the text; (2) Teachers should use the techniques of generating ideas; (3) Students are allowed to work in groups or pairs and (4) Students use some comments from their groups or pairs to their writing.

By applying those steps above, it can be concluded that learning through the integrated approach makes students have less difficulty in EFL writing since they have enough input to create their writing tasks. Therefore, using the integrated approach in the classroom has the main purpose of enabling learners to transfer the skills they have gained from each approach naturally from one mode to another and thus to produce their writing tasks efficiently.

\section{METHOD}

To accomplish the objectives of this study, a quasi-experimental research was applied to test the objective theories by examining the relationship among variables. These variables, in turn, can be measured, typically on instruments, so that numbered of data can be analyzed by using statistical procedures. This research design is a form of experimental research in which individuals are not randomly assigned to groups (Cresswell, 2012). A quasi-experimental 
design is considered appropriate since this study also attempts to investigate how the process-product hybrid approach influences students' writing skills.

This quasi-experimental study was conducted at one of the vocational high school in Kuningan Regency of West Java Province. There were 555 students of the eleventh grade acted as the population of this study, and 80 students were chosen as the sample of this study based on "the purposive sampling technique in which they were chosen based on the researcher's prior information to provide the intended data" (Fraenkel et al, 2012, p. 100). The 80 students were divided into two classes; 40 students were included to the experimental group, and the rest 40 students to the control group.

The instruments used in this study involved pre-test, treatment, post-test, and questionnaire. In collecting the data, pre-test was employed to both groups as the first step of the study. It purposed to obtain the data of the students' writing knowledge and to find out that students from both groups had the same capability of English before they received the treatment. Then, the second instrument, treatment was carried out to the experimental group to know the differences of students' improvement between two groups, so that later the writer can conclude whether the treatment was effectively improve students' writing skill or not. Third, this study employed post-test at the end of the study to measure the improvement of students' writing skills after receiving the treatment. It was employed in both groups: experimental and control group which was intended to find out the differences between students' score of both groups by using the assessment criteria of writing that covers content, organization, discourse, syntax, vocabulary, and mechanics (Brown, 2000, p. 357).
In this study, questionnaire was committed to measure the students' attitude toward the given treatment. The type of questionnaire used in this study was adapted from the tri-componential viewpoint of attitudes proposed by Oskamp \& Schultz (2005) which covers affective, behavioral, and cognitive components of attitudes. Those three components were measured by using Likert scale that asked individuals to respond to a series of statements of preference (Fraenkel \& Wallen, 2009).

In analyzing the data, T-test was used as the main test to measure the students' improvement. Before doing the T-test, there were several tests done either in pre-test or post-test which covered normality distribution, homogeneity of variance, and independent T-test. After those tests were administered, the dependent T-test was done in the end of the data analysis to compare the mean score from pre-test and post-test of the experimental group. Then, the result of students' improvement was confirmed by questionnaire in order to know the students' attitude towards the administered treatment.

\section{RESULTS AND DISCUSSION}

Tests of normality distribution and homogeneity of variance on pre-test

To test the normality distribution and the homogeneity of variance on pre-test, the Kolmogorov-Smirnov and Levene statistic were used. The null hypotheses of these tests are that the distribution of the groups' mean score is normal and the numbers of data collected from pre-test are homogenous. Therefore, the probability of normality distribution and homogeneity of variance test must be more than the level of significance ( $p$ $>0.05)$. The results are depicted in the following tables:

Table 1

Tests of Normality on Pre-test

\begin{tabular}{l|r|r|rr}
\hline & \multicolumn{3}{|c}{ Kolmogorov-Smirnova } \\
\hline & Statistic & Df & \multicolumn{2}{c}{ Sig. } \\
\hline Preex & .119 & 40 & .160 \\
\hline Precon & .117 & 40 & .181 \\
\hline
\end{tabular}


Table 1

Tests of Normality on Pre-test

\begin{tabular}{l|r|r|rr}
\hline & \multicolumn{3}{|c}{ Kolmogorov-Smirnova } \\
\hline & Statistic & Df & \multicolumn{2}{c}{ Sig. } \\
\hline Preex & .119 & 40 & .160 \\
\hline Precon & .117 & 40 & .181 \\
\hline
\end{tabular}

Table 2 Test of Homogeneity of Variance on Pre-test

\begin{tabular}{|c|c|c|c|c|c|}
\hline & & Levene Statistic & df1 & df2 & Sig. \\
\hline \multirow{4}{*}{$\begin{array}{l}\text { Pre-test } \\
\text { score }\end{array}$} & Based on Mean & .575 & 1 & 78 & .450 \\
\hline & Based on Median & .576 & 1 & 78 & .450 \\
\hline & Based on Median and with adjusted df & .576 & 1 & 77.969 & .450 \\
\hline & Based on trimmed mean & .596 & 1 & 78 & .442 \\
\hline
\end{tabular}

Based on the table 1 above, it shows that the pre-test result of the two groups are normally distributed, since the significance value of both groups are higher than the level of significance $(0.160>0.05)$ and $(0.181>$ $0.05)$. The result of homogeneity of variance test in table 2 also shows the same thing with the significance value 0.450 which indicates the data variances of both groups are homogenous and T-test can be done in analyzing the data in this study.

\section{Independent T-test on pre-test}

The independent T-test was aimed to investigate the significance difference of the data between experiment and control groups before administering the treatment. The null hypothesis used in this study is that there is no significance difference of means between two groups on pre-test. Here is the result of the independent T-test on pre-test:

Table 3

Group Statistics on Pre-test

\begin{tabular}{lllrrrr}
\hline & Group & N & Mean & Std. Deviation & Std. Error Mean \\
\hline Pre-test score & Preex & 40 & 60.55 & 9.481 & 1.499 \\
\cline { 2 - 7 } & Precon & 40 & 60.40 & 10.375 & 1.640 \\
\hline
\end{tabular}

Table 4

Independent T-test on Pre-test

\begin{tabular}{|c|c|c|c|c|c|c|c|c|c|c|}
\hline & & \multicolumn{4}{|c|}{$\begin{array}{l}\text { Levene's Test for } \\
\text { Equality of } \\
\text { Variances }\end{array}$} & \multicolumn{3}{|c|}{ t-test for Equality of Means } & \multirow{2}{*}{\multicolumn{2}{|c|}{$\begin{array}{l}\text { 95\% Confidence } \\
\text { Interval of the } \\
\text { Difference }\end{array}$}} \\
\hline & & & & & & & & & & \\
\hline & & $\mathrm{F}$ & Sig. & $\mathrm{T}$ & Df & $\begin{array}{l}\text { Sig. (2- } \\
\text { tailed) }\end{array}$ & $\begin{array}{c}\text { Mean } \\
\text { Difference }\end{array}$ & $\begin{array}{l}\text { Std. Error } \\
\text { Difference }\end{array}$ & Lower & Upper \\
\hline \multirow[t]{2}{*}{$\begin{array}{l}\text { Pre-test } \\
\text { score }\end{array}$} & $\begin{array}{l}\text { Equal } \\
\text { variances } \\
\text { assumed } \\
\end{array}$ & .575 & .450 & .068 & 78 & .946 & .150 & 2.222 & -4.274 & 4.574 \\
\hline & $\begin{array}{l}\text { Equal } \\
\text { variances not } \\
\text { assumed }\end{array}$ & & & .068 & 77.376 & .946 & .150 & 2.222 & -4.275 & 4.575 \\
\hline
\end{tabular}


By seeing the data in table 4 , it shows that the significance value of experimental and control group is 0.946 , which means that it is higher than $0.05(0.946>0,05)$ and the null hypothesis is accepted to prove that there is no significant difference between the data of the two groups. It can also be seen on table 3 that the mean score of both groups are not significantly different; the experimental group is 60.55 and the control group is 60.40 .

Based on all of the data collected from pre-test which covers normality distribution, homogeneity of variance, and independent t- test, it can be concluded that the students' writing skill was the same before being given the treatment. Therefore, the two classes were utilized as the sample.

\section{Tests of normality distribution and homogeneity of variance on post-test} It is the same as what had been done on the pre-test; the normality distribution and homogeneity of variance test were done as the main requirements to conduct $\mathrm{T}$-test in this study. And the results of both tests are elaborated in the following tables:

Table 5

Tests of Normality on Post-test

\begin{tabular}{lccc}
\hline & \multicolumn{4}{c}{ Kolmogorov-Smirnova $^{\mathrm{a}}$} & Sig. \\
\hline Postex & Statistic & $\mathrm{df}$ & $.200^{*}$ \\
\hline Postcon & .091 & 40 & .188 \\
\hline
\end{tabular}

Table 6

Test of Homogeneity of Variance on Post-test

\begin{tabular}{llccccc}
\hline & & Levene Statistic & df1 & df2 & Sig. \\
\hline \multirow{3}{*}{ Post-test score } & Based on Mean & .188 & 1 & 78 & .665 & .769 \\
\cline { 2 - 7 } & Based on Median & .087 & 1 & 78 & .769 \\
\cline { 2 - 7 } & Based on Median and with adjusted df & .087 & 1 & 73.292 & 78 & .654 \\
\cline { 2 - 7 } & Based on trimmed mean & .203 & 1 & 78 & \\
\hline
\end{tabular}

Table 5 shows that the significance value on post-test of the experimental and control group are higher than the level of significance $(0.200>0.05)$ and $(0.188>0.05)$. Likewise, table 6 shows that the significance value of the homogeneity of variance test is 0.665 higher than 0.05 . Those results mean that the mean score of the two groups are normally distributed, and the data variances of the experimental and control groups on post-test are homogenous, so the null hypothesis is accepted and T-test can be done.

\section{Independent T-test on post-test}

The independent t-test on post-test was aimed to investigate the significant different of the data collected from experimental and control group after administering the treatment. The null hypothesis of this T-test is that there is no significant difference of means between the two groups. The result of this test is depicted in the following tables:

Group Statistics on Post-test

\begin{tabular}{lllrrr}
\hline & group & N & \multicolumn{2}{c}{ Mean } & \multicolumn{2}{c}{ Std. Deviation } & \multicolumn{2}{c}{ Std. Error Mean } \\
\hline Score & postex & 40 & 75.63 & 6.582 & 1.041 \\
\cline { 2 - 7 } & postcon & 40 & 67.85 & 7.273 & 1.150 \\
\hline
\end{tabular}


Table 8

Independent T-test on Post-test

\begin{tabular}{|c|c|c|c|c|c|c|c|c|c|c|}
\hline & & \multicolumn{4}{|c|}{$\begin{array}{l}\text { Levene's Test } \\
\text { for Equality of } \\
\text { Variances }\end{array}$} & \multicolumn{3}{|c|}{ t-test for Equality of Means } & \multirow{2}{*}{\multicolumn{2}{|c|}{$\begin{array}{l}\text { 95\% Confidence } \\
\text { Interval of the } \\
\text { Difference }\end{array}$}} \\
\hline & & & & & & & & & & \\
\hline & & $\mathrm{F}$ & Sig. & $\mathrm{t}$ & df & $\begin{array}{l}\text { Sig. (2- } \\
\text { tailed) }\end{array}$ & $\begin{array}{c}\text { Mean } \\
\text { Difference }\end{array}$ & $\begin{array}{l}\text { Std. Error } \\
\text { Difference }\end{array}$ & Lower & Upper \\
\hline \multirow[t]{2}{*}{ Score } & $\begin{array}{l}\text { Equal } \\
\text { variances } \\
\text { assumed }\end{array}$ & .188 & .665 & 5.013 & 78 & .000 & 7.775 & 1.551 & 4.687 & 10.863 \\
\hline & $\begin{array}{l}\text { Equal } \\
\text { variances not } \\
\text { assumed }\end{array}$ & & & 5.013 & 77.234 & .000 & 7.775 & 1.551 & 4.687 & 10.863 \\
\hline
\end{tabular}

The data on table 8 shows that the score of both experimental and control groups indicate the significance value 0.000 which is lower than the level of significance 0.05 $(0.000<0.005)$. Therefore, the null hypothesis is rejected. It means that there is significance difference of data between the two groups. It can also be seen on table 7 that the mean score of both groups are significantly different; the experimental group is 75.63 and the control group is 67.85 .
Dependent T-test of the experimental group

The dependent t-test was used to know the significant differences of the experimental group mean score before and after having the treatment. The null hypothesis of this test is that there is no significant difference between the pre-test and post-test mean score of the experimental group. Look at the following tables which show the result of this test.

Table 9

Paired Samples Statistics of the Experimental Class

\begin{tabular}{|c|c|c|c|c|c|}
\hline & & Mean & $\mathrm{N}$ & Std. Deviation & Std. Error Mean \\
\hline \multirow[t]{2}{*}{ Pair 1} & preex & 60.55 & 40 & 9.481 & 1.499 \\
\hline & postex & 75.63 & 40 & 6.582 & 1.041 \\
\hline
\end{tabular}

Table 10

Paired Samples Test of the Experimental Class

\begin{tabular}{|c|c|c|c|c|c|c|c|c|c|}
\hline & & \multicolumn{5}{|c|}{ Paired Differences } & \multirow[b]{3}{*}{$\mathrm{t}$} & \multirow[b]{3}{*}{ df } & \multirow[b]{3}{*}{ Sig. (2-tailed) } \\
\hline & & \multirow[b]{2}{*}{ Mean } & \multirow{2}{*}{$\begin{array}{c}\text { Std. } \\
\text { Deviation }\end{array}$} & \multirow{2}{*}{$\begin{array}{c}\text { Std. Error } \\
\text { Mean }\end{array}$} & \multicolumn{2}{|c|}{$\begin{array}{c}95 \% \text { Confidence Interval of the } \\
\text { Difference }\end{array}$} & & & \\
\hline & & & & & Lower & Upper & & & \\
\hline Pair 1 & $\begin{array}{l}\text { preex - } \\
\text { postex }\end{array}$ & -15.075 & 9.908 & 1.567 & -18.244 & -11.906 & -9.623 & 39 & .000 \\
\hline
\end{tabular}

By seeing the data on table 9, the data shows that students' mean score increased after having treatment. It can be seen that the pre-test mean score of the experimental class is 60.55 and the post-test mean score increased up to 75.63. The significance value on table 10 also supported the increasing of the experimental mean score during the study by resulting 0.000 lower than the significance level 0.05. Based on such results, it is concluded that the null hypothesis is rejected which means that there is significant difference between the pre-test and post-test mean score of the experimental class, 
indicating that the process-product hybrid approach can be an effective approach to improve students' writing skill.

To confirm the students' improvement in writing skill, this study was supported by the result of students' attitude test in terms of questionnaire and the result was stated below:

1. Affective Aspect

$87.5 \%$ of the students like writing, $100 \%$ agree that it's hard to get good score in writing and $100 \%$ like writing by using process-product hybrid approach.

2. Behavioral Aspect

Most of the students agree that they are more enthusiastic and easier to get good score in learning writing comprehension by using this integrated approach resulting $97.5 \%$, and $100 \%$ agree that it can serve them the more interesting learning activities which affect their achievement in writing.

3. Cognitive Aspect

$97.5 \%$ of the students agree that this approach can give them the full comprehension and improve their skill in writing.

\section{CONCLUSION}

Based on the results and discussion presented in the previous section, this study proved that the use of process-product hybrid approach in students' writing activities has a significant influence in improving students writing skills. This proof is supported by the data collected from instruments which resulting total mean score of the experimental group pre-test 60.55 improve to 75.63 . It means that the processproduct hybrid can be an effective approach to improve students' writing skills.

Besides proving the result by comparing the means of pre-test and post-test, the students' attitude was also measured in questionnaire to confirm the result of this research. The result of the questionnaire reveals that almost all of the students give positive responses to the use of processproduct hybrid approach in their writing activities. Such result indicates that this approach has a strong effect in improving students' writing skills, as they agree that it can raise the students' interest in learning and give the full comprehension of their writing skills.

\section{REFERENCES}

Badger, R. and White, G. (2000). A process genre approach to teaching writing. ELT Journal 54(2). 153-160.

Boughey, C. (1997). Learning to write by writing to learn. ELT Journal, 51(2), 126-134.

Brown, H. D. (2000). Teaching by principles: An interactive approach to language pedagogy $\left(2^{\text {nd }}\right.$ ed.). California: Longman.

Cresswell, J. W. (2012). Educational research (4th ed.). Boston: Pearson.

Fraenkel, J. R., \& Wallen, N. E. (2009). How to design and evaluate research in education ( $7^{\text {th }}$ ed.). New York: McGraw-Hill Higher Education.

Fraenkel, J.R., Wallen, N.E., \& Hyun, H. H. (2012). How to design and evaluate research in education $\left(8^{\text {th }}\right.$ ed.). New York: McGraw-Hill Higher Education.

Harmer, J. (2001). The practice of English language teaching ( $3^{\text {rd }}$ ed.). Essex: Longman.

Harmer, J. (2004). How to teach writing. Essex: Longman.

Hasan, K. Md. \& Akhand, M. M. (2010). Approaches to writing in EFL/ESL context: balancing product and process in writing class at tertiary level. Journal of NELTA 15(1), 77-88.

Kim, Y. \& Kim, J. (2005). Teaching Korean university writing class: Balancing the process and the genre approach. Asian EFL Journal 7(2) 1-15

Miri, T. (2014). Toward finding an approach for improving rhetorical organization of EFL learners' argumentative writing. International Journal of Applied Linguistics \& English Literature 3(3), 164-170.

Mourssi, A. (2013). Theoretical and practical linguistic shifting from product/guided writing to process writing and recently to the innovated writing process approach in teaching writing for second/foreign language learners. International Journal of Academic Research in Business and Social Sciences, 3(5), 731-751.

Nunan, D. (1989). Designing tasks for the communicative classroom. Cambridge: Cambridge University Press.

Oskamp, S., \& Schultz, P. W. (2005). Attitudes and opinions. New Jersey: Lawrence Erlbaum Associates.

Richards, J. C. \& Renandya, W. A. (2002). Methodology in language teaching: An anthology of current practice. Cambridge: Cambridge University Press.

Tangpermpoon, T. (2008). Integrated approaches to improve students writing skills for English major students. ABAC Journal 28(2), 1-9.

Tribble, C. (2003). Teaching writing. PhD Manuscript. 136

Tuan, L. T. (2011). Teaching writing through genrebased approach. Journal of Theory and Practice in Language Studies 1(11), 1471-1478.

White, R. (1981). Approaches to writing guidelines. London: Longman Publishers. 